\title{
Erratum to: A real time surface electromyography signal driven prosthetic hand model using PID controlled DC motor
}

\author{
${\text { Retheep } \text { Raj }^{1} \cdot \text { Rejith Ramakrishnan }^{1} \cdot \text { Karingannikalam Subramanian Sivanandan }}^{1}$
}

Published online: 23 January 2017

(C) Korean Society of Medical and Biological Engineering and Springer 2017

Erratum to: Biomed Eng Lett (2016) 6:276-286

DOI 10.1007/s13534-016-0240-4

Unfortunately, there are typos in the second author's last name and third author's first name in the published article. The corrected names are shown in this erratum.

The online version of the original article can be found under doi:10.1007/s13534-016-0240-4.

Retheep Raj

retheepraj@gmail.com

1 Department of Electrical Engineering, National Institute of Technology, Calicut, India 